\title{
Analysis of the Motifs of Animation Film "Coco"
}

\author{
Xuexin Du \\ Nanyang Institute of Technology, Nanyang, Henan Province, China \\ moonriverr@163.com
}

Keywords: Coco, Animation Film, Motif

\begin{abstract}
The release of the American Cartoon Film Coco has caused an upsurge and has received excellent box office income and reputation in the world including China. The film tells of the bizarre experience of the Mexican boy Miguel on the Day of the Dead. Its great success has benefited from the accurate grasp of narrative motifs. Its main narrative motifs include dream and kinship motif, death motif, mythical animal motif, and trauma motif. The thesis takes the motif as the starting point to analyze how the film uses these narratives in animation films to realize entertainment function and education function.
\end{abstract}

\section{Introduction}

Animation Film Coco tells the audience a story of a Mexican boy Miguel who came to the world of souls by accident on the "Day of the Dead"- a Mexican holiday celebrated throughout Mexico. The film organizes the plot with typical motifs: dream motif and kinship motifs, death motif, mythical animal motif, and trauma motif. These motifs are trans-period, trans-national, and cross-cultural. The author holds that the use of these motifs is what leads to the success of the film. The study of this film intends to analyze how these motifs are used to achieve the functions of entertainment and education. The paper is expected to provide a new perspective to the appreciation of animation films. Because of its popularity in China, to better the functions of motifs, the author intends to compare the different understandings of the same motif between China and the United States when necessary.

American folklorist Stith Thompson holds that motif is the smallest narrative element of the theme, which can be classified into various types [1]. It may include human basic behavior and spiritual phenomenon like life, death, parting, love, time, space, season, ocean, mountain range, night, etc. Motif has the great power to generate a variety of themes. Since motif itself does not contain a preference for any conception, people in different cultural backgrounds may have different attitudes toward the same motif. It is these familiar motifs which were placed in the exotic scene of the Day of the Dead in Mexico combined with its unique cultural elements that makes a fantasy and touching story.

\section{Dream and kinship motif}

Dream and kinship motifs are the unavoidable topics in many films. When there is a clash between dream and kinship, dream and conscience, how should one choose? The film gives the audience some enlightenment with the stories of three main characters- Miguel, Hector and Da-la-Cruz.

In order to pursue his dream of music, Miguel signed up for the talent contest of the Day of the Dead. But his family never mentions music in their daily life because they believe their ancestor has ever abandoned the family because of his pursue of his music dream. Naturally they are opposed of his decision. Miguel's grandma even broke his guitar to prevent him from music. In order to realize his dream, Miguel ventured into the cemetery of the dead star singer De la Cruz, trying to "borrow" his guitar hanging in his coffin chamber. When he played his guitar, he magically strayed into the souls of the dead. He came close to joining the dead as well, unless he could get the blessing of these dead relatives. In order to realize his dreams, he rejected his great great grandmother's blessing with the condition of "never touch the music". In order to get the blessings of the star singer De la Cruz 
whom he had mistaken for his grandfather, He was not afraid of difficulties and went through various twists and turns to find him. The strong perseverance, wit, and even crafty embodies the determination and will of a dream-seeker go beyond many ordinary people, which is very much in line with the public's psychological expectations of a dream-seeker.

In addition to his own passion for music, Meg's firm determination to be a great singer is largely inspired by the seditious words of De la Cruz. There have been several times of brainwashing famous quotes "seize your moment" in the film. "I'm done asking permission. When you see your moment, you mustn't let it pass you by". De la Cruz's thirst for success reflects the distortionary understanding of success in today's society, that is, desperate for success. Some people abandoned their affections, friendships, even what makes a human being, and committed monstrous crimes just to fish for fame and credit. Dracula is typical of this kind. In order to become a singer, he brutally poisoned his companion, Hector, and marched on the corpse of others to the top of his success. When his crimes were exposed by Miguel, he defended himself: "Success doesn't come for free. You have to be willing to do whatever it takes to seize your moment." Behind his "inspirational" discourse, it is the revelation of the pursuit of unscrupulous success by some people under the control of consumerism and mass media. In their world, glamorous celebrity life is his value, which is worthy exchanging for life. Kinship is only a stepping stone to success. When family and dream conflict with each other, kinship becomes a victim.

Meg's grandfather Hector was a great singer who left his family when he was young. But the attachment to family and affection made him gradually tired of the wandering life. Finally, he gave up the so-called "success of career" and decided to return home. But his partner and good friend De la Cruz was eager to be successful and needed Hector's cooperation to be famous. So he hated Hector because Hector's decision smashed his dream. In order to steal Hector's song, he poisoned him, resulting in Hector's family thinking that Hector abandoned the family completely.

The murder caused Hector great sufferings in the dead world because there is a rule in the dead land: The dead must be remembered by their families in order to survive in the world of the dead. But unfortunately, misunderstood by his family, Hector was deliberately forgotten by them. As a result, he became a wanderer in the soul world and could not go back to the living world to spend time with his family on the Day of the Dead. Although he passed away for many years, he always missed his daughter Coco. Every year on the Day of the Dead, he tried various methods to return to the living world and reunite with his family. However, because his family members refused to put up his photo, there is no way for him to go back. When he said to Miguel that "Nothing is more important than family", he was actually regretting his ignoring his family when pursuing his dream. It is this sentence with so gentle affection that touches the audiences who are away from hometowns and chasing the so call "success". Just as the famous playwright Robert McGee said: A good story can provide audience with double happiness. First, the story makes the audience discover a strange world. Second, as the audiences enter the strange world, they discover ourselves; in this double discovery, we can experience the meaning of life... [2] The audience was deeply touched by the words of Hector. They resonate with the character and deeply understand the value of family and the responsibilities of the living people. They also gained a strong sense of identity and satisfaction.

The kindship in the film that spans life and death is more likely to trigger people's thinking and touch the softest part of human beings, thus producing a huge appeal.

Although the dream and affection motifs are clichés and seemingly have no new ideas, the contradictions and disputes between them are unavoidable themes in a constantly changing society, and hence have a powerful generation of good stories. The dream motif is in harmony with the pursuit of fame and interests under the modern consumer social environment. It resonates with most people, and the kinship motif generates the audience's feeling of human's initial love and the sense of belonging. The conflicting motifs reveal the confusion of modern people, while the plot structure of Miguel's "runaway-growth-return" provides a spiritual light to stray people who fall into the dilemma between dream and kinship. In the two worlds of mortal and living, the film explains the 
essence of kinship and leads people to notice the value orientation and realizes the missionary function.

\section{Death motif}

Though death is a common motif in literary works, different countries or regions have great differences in their understanding of death. The Day of the Dead shows the unique understanding of death of Mexican people. It is a traditional holiday in Mexico and takes place on November 1st - 2nd each year. The Mexicans believe that the spirits of their ancestors will return to the living world along the path paved with marigold petals during this period, and will spend a happy time with the living family.

The beginning of the film shows us the exotic tradition of the festival for the dead. The first thing that catches the eye is the colorful Mexican paper-cut hanging on the streets and in the houses which creates a cheerful festive atmosphere. The marigold petals are scattered on the streets and at homes. Photos of the dead are put up on the altar. Marigolds, food, candles, and items that the deceased liked during his lifetime are also put on the altar level by level. To welcome their loved relatives back from the dead world, the whole family is busying preparing with joy and enthusiasm.

Octavio Paz, a famous Mexican writer and winner of the Nobel Prize for literature makes comments on the perception of death by Mexicans: For people in New York, Paris or London, death is something they will not mention easily, because the word will burn them. The Mexicans are familiar with death, joke about it, caress it, sleep with it, and celebrate it. It is one of their favorite playthings and most steadfast love.

The spiritual world in the film is not ghastly and full of evil spirits. It is colorful and bizarre. The high bridge, bright and towering buildings, convenient living facilities, colorful entertainment life reflect the calm, open-minded, positive and optimistic attitude of Mexicans towards death.

Contrasted with Mexican's attitude toward death, traditionally, Chinese people pay homage to its ancestors with a solemn mood. In this way, they remember the dead and express their grief. It is generally believed that once people die, yin (the dead world) and yang (the living world) are separated and never meet each other. Affected by the Buddhism six rounds of reincarnation, Chinese people' mind are full of uncertainty about the destination of their dead relatives, and therefore are full of fear of death. In the eyes of the Chinese, death is a very ominous word. When Confucius, the famous educator in ancient China, was questioned by a disciple about afterlife, he only replied: "Who knows not how to live, knows not how to die" [3]. By saying this he holds that people should focus on handling the how to live a meaningful life. In this way, Confucius deliberately evades the issue of death.

The moving scene in the film is the permanent death of a poor guy name Chicharron who was forgotten by people in the living world. At the time of his death, he begged Hector to play his favorite song for him to express his love for his most beloved. When the music was over, Chicharron's hat fell quietly, seeing this sad scene, many viewers shed tears immediately. This close-up enables people to deeply understand the value of family's affection and care for others, which enable people to recognize the beauty of kinship and the responsibility of their respective life roles.

The movie's concept of death provides a new perspective on death education, namely, fulfilling its responsibilities in its lifetime, facing it full at ease, cherishing the time you have shared with your family, and creating wonderful memories with family members. The death theme, the cognitive contrast in different cultural contexts, makes this film uniquely attractive, increases the viewing experience, and also proclaims the universal value of cherishing affection.

\section{Mythical animal motif}

Mythical animals are one of the important motifs of human literary creation because they appear in almost all folk tales in the world. In S. Thompson' works Motif-index of folk-literature: $a$ 
classification of narrative elements in folktales, ballads, myths, fables, medieval romances, exempla, fabliaux, jest-books, and local legends, he listed various animals which appear in stories in different countries [4]. It is generally believed that mythical animals sprouted from the humankind childhood when the productivity was low. In the face of the powerful natural world, the ancestors created a blind worship of "everything has a spirit". In the struggle with nature, they hoped to utilize powerful animals to make up for their limitations. This is the source of ancient myths and legends.

The mythical colorful animal named Pepita with extraordinary power punishes evil and promotes goodness, inevitably becoming the highlight of the film. Spiritual animals such as cats, monkeys, and hedgehogs which are unique to Mexican folk beliefs are called alebrije by local people. They are diverse in shape, possess a powerful force against evil, and are responsible for guiding the dying to the spiritual world. These animals add mysterious and bizarre effects to the film.

The great power of these animals is manifested several times in the film. Pepita emerged in time when Miguel was in danger. He also rescued Miguel and his grandfather, Hector, from the abyss and punished Da la Cruz mercilessly when his crime was exposed. The hairless dog "Dan" belongs to the Mexican-specific "xolo" and its name is derived from the Xoloitzcuitle, the god of the Aztecs of Mexican aborigines. This dog is considered to be a deity and can also connect the living world with the world of spirit. In the spirit world, he transformed into a colorful, flying alebrije, He appeared suddenly when Miguel was thrown down from the high platform by Da la Cruz and saved him with the help of Pepita. The mythical animal played an important role in the gradual process of this film's narrative and formed a rich tension in the plot.

There have been various evolutionary forms of the mythical animal motif since ancient times in various folk tales and fantasy novels in different countries of the world. For example, there are many descriptions of mythical animals in China's "Shan Hai Jing". Also in the novel "Journey to the West", the four bodhisattvas each have their own mount and these mounts can all summon the wind and the supernatural power [5]. There are also a large number of mythical animals. They either assist the master in the battle, or guard their owner's safety. Even some animals have the function of judging good and evil. For example, the officials of the pre-Qin period in China used the animal named "Xiezhi" to distinguish good from evil. This is the famous "Xiezhi settling lawsuit". The civet named Pepita in the film has the ability to punish evils and help others. The hairless dogs have also identified the start singer De la Cruz as a counterfeit item from the very beginning and Miguel's real great great grandfather is Hector.

Whether it is Chinese mythological animals or alebrije in the film, these animals are mostly incarnation of justice and have supernatural power. The use of the mystical motif not only produces bizarre effects and wonderful colors in the setting of the story, but also reflects the artist's extraordinary imagination. It not only fits the local culture of Mexico, but also triggers the cultural identity of the audience and satisfies the audience. A surrealistic expectation creates an alienated aesthetic that alienates real life, and realizes the entertainment function of animated films.

\section{Trauma motif}

The English name of the film is Coco and its Chinese translation is "Xun meng huan you ji" meaning "the journey of seeking one's dream". Although the translation suggests the content of the film, it overlooks a key figure: Coco. Coco is the great grandmother of the protagonist Miguel and is the main driving force of the story. Her birth changed the focus of her parents' lives. She is the main force that can pull back his wandering father Hector to the family. It was her memory of her father that guarantees her father's living in the spiritual world. But the loss of fatherly love in her young age is a great trauma in her life. Her emotion changes from feeling her father's love to losing her father's love, from craving for her father's love to despairing of her father's love. It finally develops into the resentment of his father. Thus, the trauma of the absence of the father's love accompanied her following life.

Trauma, originally a medical term, usually refers to the intense threat posed to an individual. 
Now it is widely used in cultural or literary analysis. In his book The Experience of Silence, Carus pointed out that trauma is a sudden, catastrophic and unavoidable experience. People's reaction to this event is often delayed, uncontrollable, and passes through hallucinations or in other ways [6].

The photo of the family with the father missing on the altar shows how hateful she is at her father. Though it was not clear who tore off the father's photo, we can infer that it was Coco who didn't intend to put it up. Traditionally, the photo was put up by the deceased's descendants. After Coco's parents died, Coco is the only descendent, but she still left his father's position blank, indicating that she was deeply hurt by her father, she just wanted to forget the trauma of being deserted by his father. However, subconsciously, there is still deep love for my father. At her old age, she suffered from memory loss. She forgot who her daughter was, and she forgot all other relatives. She almost forgot everything, but the only memory was that Daddy was coming back. When Miguel accidently mentioned her father, she seemed recovered her memory suddenly: "Papa, Papa's back". It can be seen how strong her deep love for her father is and how she hungers for her father's love.

When Miguel sang the song Remember Me written specifically for Coco by her father, her seemingly petrified body loosened slowly. The warm scene with dad seemed to emerge again. The song brought her father's love back to her heart. The song brought her back to that warm and happy childhood. The song made her realize that she had always been loved by her father. In the end, Coco chose to forgive, she found the upper part of her father's picture, and synthesized a complete picture with the original broken photo, and restored its original appearance. This image symbolizes her forgiveness to her father and the healing of her own soul trauma. When life is about to come to an end, Coco completes the redemption of herself and the salvation of his father's soul. Although the traumatic motif is concealed in the plot, it is a powerful feature because it is at the critical stage of the narrative of life and death. Not only does it alert the parents that they cannot be absent during the growing period of their childhood, it also reminds the children to learn to understand and forgive their parents in order to complete the two-way salvation.

\section{Conclusion}

The animation film Coco, which was co-produced by Walt Disney Studios and Pixar Animation Studios, uses Mexico's unique cultural elements as the background of a typical kinship story. It utilizes common motifs which belong to most cultures such as dream motif, kinship motif, death motif, magical animal motif and trauma motif etc. With these motifs a narrative structure and a touching story were formed. Contrasted with classic Hollywood Disney animation that mainly uses European and American cultural circles as materials, this film uses other culture to suit global communication. The success of this film is based on the above-mentioned motifs. It perfectly realizes the functions of entertainment and education and publicizes positive and universal values.

\section{References}

[1] Stith Thompson. The folktale [M].New York: Holt,Rinehart and Winston, Inc., 1946.

[2] McKee R. Story: style, structure, substance, and the principles of screenwriting [M]. Harper Collins, 1997.

[3] Waley A. The analects of Confucius [M]. Routledge, 2012.

[4] Thompson S. Motif-index of folk-literature: a classification of narrative elements in folktales, ballads, myths, fables, mediaeval romances, exempla, fabliaux, jest-books and local legends [M]. Indiana University Press, 1989.

[5] Anthony C. Yu. The journey to the west: v.2 [M]. University of Chicago Press; Revised edition, 2013.

[6] Caruth C. Unclaimed experience: Trauma, narrative, and history [M]. JHU Press, 2016. 